\title{
Pembuatan Sistem Administrasi Pendidikan Berbasis Android
}

\author{
Yudha Pradana ${ }^{a}$ Andi Aulia Tsuraya ${ }^{b}$ \\ a,b Politeknik Negeri Media Kreatif
}

\section{INFORMASI ARTIKEL}

Sejarah Artikel

Diterima Redaksi: 04 Mei 2021

Diterbitkan Online: 31 Juli 2021

KATA KUNCI

Aplikasi Android

Sistem Informasi Manajemen

Administrasi Pendidikan

KORESPONDENSI

Email : yudha.pradana@gmail.com

\section{A B $\mathbf{S}$ T $\mathbf{R}$ A $\mathbf{C}$ T}

Kebutuhan administrasi pendidikan bagi pengajar tentu hal yang tidak dapat dilepaskan dalam pelaksanaan tugas dan fungsi guru. Namun demikian terkadang pelaksanaan administrasi pendidikan menambah beban tugas guru. Kemajuan teknologi dan informasi dapat disinergiskan dengan pelaksanaan administrasi pendidikan, salah satunya ialah melalui pembuatan administrasi pendidikan dengan menggunakan smartphone berbasis android. Rumusan masalah dalam penulisan ini ialah bagaimana pembuatan administrasi pendidikan berbasis android. Tujuan penulisan ialah untuk mengetahui pembuatan administrasi pendidikan berbasis android. Tahapan pembuatan aplikasi melalui tahap praproduksi, produksi, dan pascaproduksi. Aplikasi ini dibuat dengan memuat administrasi pendidikan meliputi kalender akademik, program sentra, data siswa, dan data guru. Dengan adanya administrasi pendidikan berbasis android ini diharapkan dapat memudahkan tugas pengadministrasian oleh guru dan mengintegrasikan administrasi pendidikan yang dilaksanakan oleh satuan pendidikan.

\section{PENDAHULUAN}

Bagi seorang guru dan pelaksanaan pendidikan di satuan pendidikan, administrasi pendidikan merupakan hal yang tidak dapat dihindari keberadaannya. Administrasi pendidikan yang dilakukan akan menentukan kelancaran pengelolaan sistem pendidikan yang dilakukan. Namun demikian soal administrasi pendidikan ini terkadang menjadi permasalahan bagi guru dan satuan pendidikan. Bagi guru, permasalahan muncul karena adanya kewajiban pelaksanaan administrasi pendidikan malah menjadi penambah beban tugas sehari-hari. Bagi satuan pendidikan, ketika administrasi pendidikan yang dibuat oleh guru tidak tertib tentu akan menghambat kinerja satuan pendidikan secara keseluruhan.

Kemajuan teknologi dan informasi dapat diseleraskan dengan pelaksanaan administrasi pendidikan. Terlebih dengan penggunaan smartphone berbasis android sebetulnya dapat menjadi peluang dalam memudahkan pelaksanaan administrasi pendidikan yang dilakukan oleh guru. Oleh karenanya sangat memungkinkan perancangan sistem administrasi pendidikan dengan menggunakan sarana smartphone berbasis android.

Menurut Asnawir (2005), administrasi pendidikan merupakan aplikasi ilmu administrasi dalam kegiatan pembinaan, pengembangan dan pengendalian usaha-usaha pendidikan yang diselenggarakan dalam bentuk kerjasama
Pelaksanaan administrasi pendidikan menurut Hadari Nawawi (1997) dapat juga dijadikan sebagai usaha pengendalian rangkaian kegiatan kependidikan yang terarah pada pencapaian tujuan pendidikan yang hendak dicapai oleh kelompok kerjasama yang menyelenggarakan usaha kependidikan.

Sinergi pelaksanaan administrasi pendidikan dengan kemajuan teknologi dan informasi yang menjadi landasan penulis salah satunya dari pendapat Ahmad Musyafa (2017) yang mengemukakan bahwa sistem informasi berbasis komputer akan sangat membantu suatu instansi pendidikan untuk mendapatkan informasi yang cepat, tepat, dan akurat dalam memberikan laporan.

Hal lain yang melandasi pembuatan aplikasi ini ialah dengan mengacu pada kesimpulan riset Honkins (2017) bahwa sistem informasi manajemen pendidikan diharapkan dapat memudahkan orang tua siswa untuk mengetahui seluruh informasi kegiatan sekolah dan juga dapat menjadi peluang untuk meningkatkan daya saing dilingkungan sekitarnya.

Terlebih penggunaan sistem ini dalam administrasi pendidikan dapat dioptimalkan sebagai untuk manajemen organisasi, dalam hal ini adalah satuan pendidikan, seperti diutarakan Gordon B. Davis (2002) bahwa sistem informasi manajemen adalah sebuah sistem manusia dan mesin yang terpadu (integrated) untuk menyajikan informasi guna mendukung fungsi operasi, manajemen, dan pengambilan keputusan dalam sebuah organisasi. 
Perancangan aplikasi yang akan dibuat adalah aplikasi yang memberikan informasi admnistrasi sekolah berbasis android. Aplikasi ini memberikan informasi program tahunan dan semester, isian silabus, data guru dan siswa, kalender akademik serta agenda guru setiap harinya. Aplikasi ini memudahkan guru untuk mendapatkan informasi dan mengakses informasi yang berhubungan dengan administrasi sekolah.

Rumusan masalah yang ditetapkan ialah bagaimana pembuatan administrasi pendidikan berbasis android? Tujuan penulisan ialah untuk mengetahui pembuatan administrasi pendidikan berbasis android.

Batasan dalam penulisan ini meliputi:

1. Aplikasi dibuat berbasis android dan digunakan pada perangkat smartphone

2. Aplikasi yang dibuat dapat digunakan oleh guru sebagai pengguna dan tenaga kependidikan sebagai admin

3. Aplikasi hanya memuat jumlah murid serta guru, jadwal mengajar guru, kalender akademik, program tahunan, program semester dan isian silabus.

\section{PEMBAHASAN}

Sebelum membuat aplikasi administrasi pendidikan ini, penulis menganalisis kebutuhan dengan cara mengobservasi kegiatan administrasi yang sudah ada dan melalui pendalaman data dengan mewawancarai guru. Dari hasil telaahan tersebut diketahui bahwa selama ini pelaksanaan administrasi masih bersifat tercetak sehingga terkadang menghasilkan tumpukan data dan tersebar sehingga diputuskan pembuatan aplikasi administrasi pendidikan berbasis android dengan asumsi mudah digunakan dan bersifat responsif serta dengan dasar efektifitas pelaksanaan administrasi.

Selain itu penulis melakukan analisis SWOT (strength, weakness, opportunities, and threats) untuk mengetahui kemungkinan-kemungkinan yang akan penulis hadapi dalam pembuatan aplikasi ini. Analisis SWOT yang dilakukan menemukan hasil sebagai berikut:

1. strength: memudahkan guru dalam mencari informasi seputar administrasi sekolah.

2. weakness: aplikasi yang harus diunduh terlebih dahulu dan user harus mempunyai smartphone dimana spesifikasinya yang sesuai dengan aplikasi.

3. opportunity: dapat menjadi sarana yang sangat baik untuk memudahkan para guru mendapatkan berbagai informasi administrasi sekolah.

4. threat: keamanan sistem informasi yang harus selalu terjaga dengan kuat.

Kemudian penulis melakukan analisis kebutuhan dalam pembuatan aplikasi ini yang berupa kebutuhan fungsional dan non-fungsional. Kebutuhan fungsional dalam pembuatan aplikasi ini didapat setelah melakukan wawancara dan curah pendapat bersama pihak lain yang berupa: terdapat menu sign untuk dapat mengakses aplikasi ini, terdapat menu utama guna mempermudah pengguna dalam mendapatkan informasi dan mengakses aplikasi, dan terdapat pemberitahuan/notifikasi jadwal kegiatan harian guru.

Sedangkan kebutuhan non-fungsional meliputi:

1. Perangkat Keras:
Laptop dengan spesifikasi

a. Architecture: ASUS UX305F AMD A6 4400M APU Radeon HD Graphics

b. Memory: $4 \mathrm{~GB}$

c. Operation System: Windows 10 Ultimate 64-bit

2. Perangkat Lunak:

a. Windows 10 sebagai operation system yang menghubungkan antara perangkat keras dengan berbagai perangkat yang terdapat pada komputer sehingga dapat saling terintegrasi.

b. Android Studio untuk pengembangan aplikasi sehingga aplikasi dapat dijalankan dan digunakan oleh pengguna.

c. Adobe Photoshop CS 6 untuk pengeditan foto atau gambar.

d. Bootstrap untuk perancangan web server admin, sehingga admin dapat menyimpan data dan mengupload data ke aplikasi.

e. Adobe Illustrator untuk pembuatan desain user interface aplikasi

f. Database Server untuk penyimpanan kumpulan data yang disimpan secara sistematis didalam komputer. Program komputer yang menyediakan layanan data untuk di salurkan ke komputer lain atau program komputer lainnya, jadi istilahnya layanan dari komputer database di salurkan kepada komputer lain dengan kode program komputer yang sudah ditentukan.

Penulis juga melakukan strategi perancangan karya dari segi desain aplikasi yang meliputi pewarnaan dan pemilihan huruf dengan memperhatikan perbandingan dengan aplikasi lain yang penulis temukan. Strategi perancangan karya juga dilakukan dengan memperhatikan karakter target audiens dengan tampilan desain yang eye catching dengan warna soft dengan cara penggunaan yang mudah dimengerti oleh pengguna. Sebagai media sistem informasi administrasi sekolah yang baru melalui aplikasi ini dapat memberikan informasi seputar administrasi sekolah kepada pengguna yang dapat diakses dari berbagai menu yang ada.

Visualisasi desain yang dipilih dengan menggunakan visualisasi gaya grafis vektor modern atau flat design. Pewarnaan yang dipilih menyesuaikan dengan mandatory yakni warna kuning, putih, dan hijau. Sedangkan jenis huruf yang dipilih ialah Arial, karna jenis huruf seperti ini lebih tegas, bersifat fungsional dan lebih modern. Font yang penulis gunakan adalah font Arial. Sifat huruf ini kurang formal, lebih mengesankan karakter minimalis, mudah dibaca, hangat dan interaksi sosial.

Selanjutnya dalam proses pembuatan aplikasi, penulis dalam tahap awal pembuatan aplikasi informasi administrasi dicari ide, peluang, mempelajari materi yang akan dibuat, menyempurnakan konsep, mencari referensi, membuat sketch user interface dari konsep, kemudian masuk ke langkah selanjutnya yaitu tahap konsep desain, desain tipografi, pemrograman, hingga sampai ke tahap finishing.

Penulis juga menentukan use case untuk mengetahui fungsi apa saja yang ada di dalam sebuah sistem dan siapa saja yang berhak menggunakan fungsi-fungsi tersebut. Sebuah use case mempresentasikan sebuah interaksi antara actor (user atau sistem lainnya) dengan sistem. 


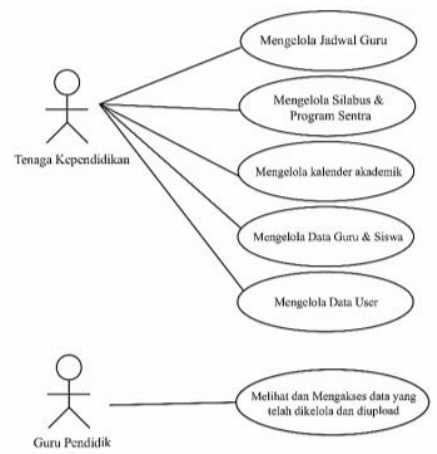

Gambar 1 Use Case Diagram Aplikasi Sumber: penulis

Untuk pembuatan aplikasi ini dibutuhkan beberapa tahapan yang meliputi konsep interaktif yang dibutuhkan dari aplikasi sistem informasi ini. Sehingga pengguna dapat langsung memahami cara penggunaan aplikasi. Dalam pembuatan aplikasi ini konsep grafis yang digunakan adalah pembuatan asset desain, user interface aplikasi beserta prototype, penyusunan data di data base, pembuatan web admin dan perancangan aplikasi menggunakan android studio.

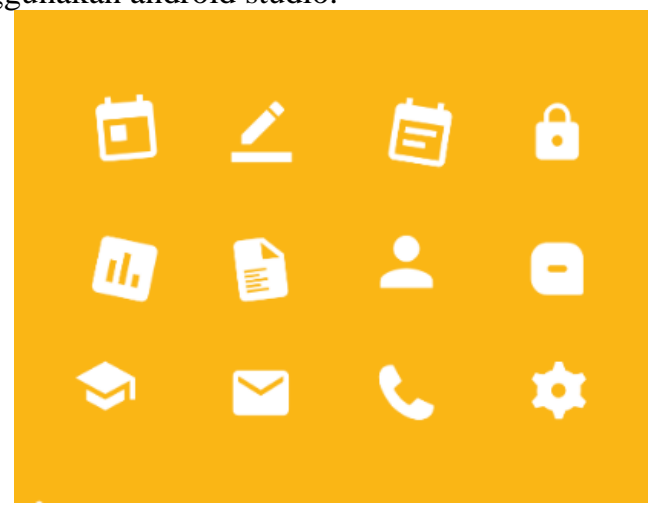

Gambar 2 Icon Aplikasi

Sumber: penulis

Pembuatan user interface dalam aplikasi ini juga menentukan bagaimana aplikasi akan digunakan. Sketsa user interface penempatan ikon atau konten konten yang akan di buat, selain mempermudah dalam pengerjaan sketsa awal juga menjadi panduan dalam memvisualkan desain sehingga hasil akhir tidak terlalu menyimpang dari konsep awal. User interface yang dibuatkan sketsanya memuat halaman awal, menu utama, dan sub menu.

Aplikasi ini memuat halaman login yang digunakan oleh pengguna dengan terlebih dahulu membubuhkan user dan password. Halaman login tergambar sebagai berikut:

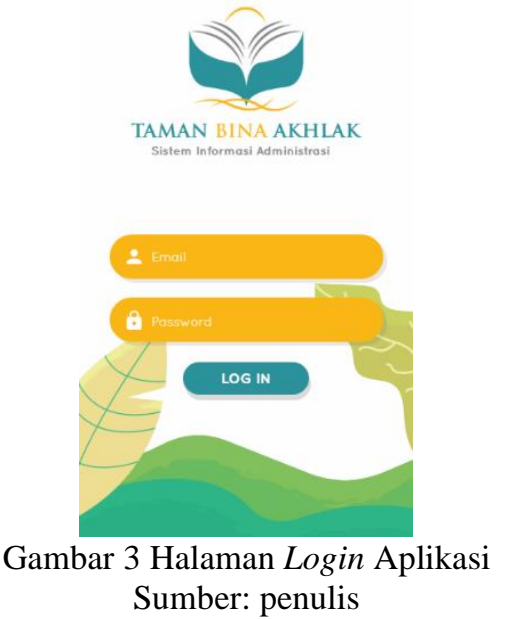

Halaman menu memuat pilihan-pilihan yang dapat digunakan oleh pengguna sesuai dengan tujuan penggunaan yang terdiri dari kalender akademik, program sentra, data siswa, dan data guru.

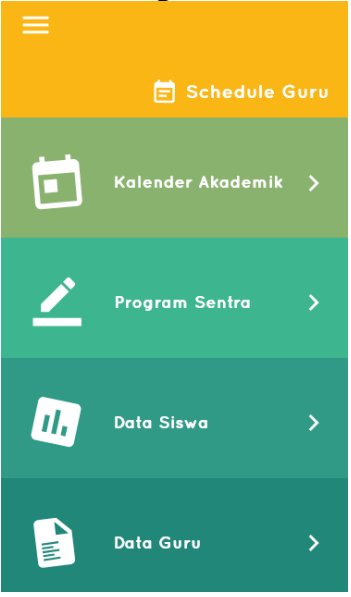

Gambar 4 Halaman Menu Aplikasi Sumber: penulis

Halaman Schedule Guru berisi tentang jadwal yang dilakukan oleh guru selama semester berlangsung. Menu ini diisi oleh guru sesuai dengan kegiatan yang akan mereka lakukan.

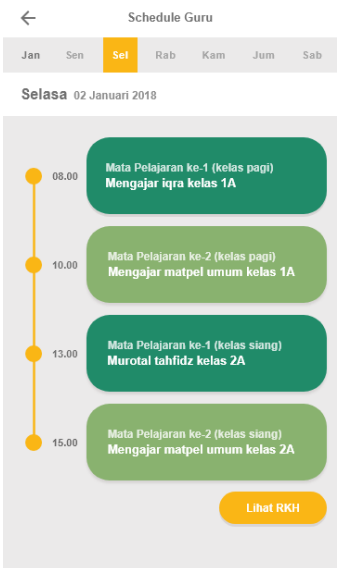

Gambar 5 Halaman Schedule Guru Sumber: penulis 
Menu kalender akademik memuat rangkaian kegiatan yang terjadwal dalam kalender. Kalender akademik sesuai dengan kalender sekolah yang di-breakdown oleh guru sesuai dengan program semester.

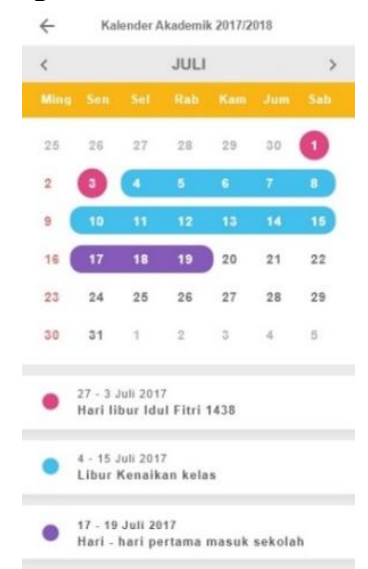

Gambar 6 Halaman Kalender Akademik Sumber: penulis

Program sentra berisi tentang program pembelajaran yang akan dilaksanakan oleh guru.

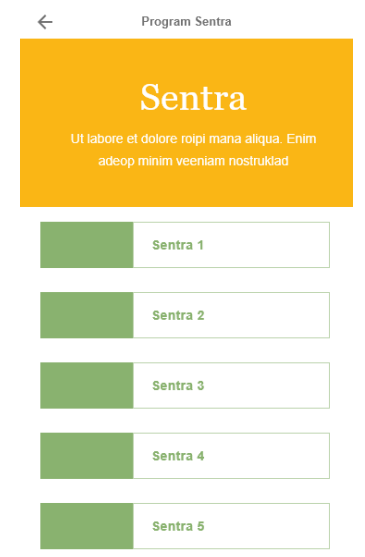

Gambar 7 Halaman Program Sentra

Sumber: penulis

Halaman data siswa berisi tentang data siswa per kelas dan dapat digunakan sebagai sarana presensi oleh guru.

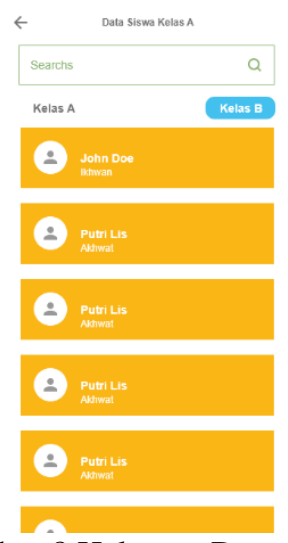

Gambar 8 Halaman Data Siswa

Sumber: penulis
Setelah pembuatan asset desain dan user interface selesai, tahap selanjutnya adalah pembuatan database. Sebelum pembuatan web admin, pembuatan database sangat dibutuhkan sebagai penyimpanan data yang dinggah pada web admin. Pada proses pembuatan database ini penulis menggunakan XAMPP untuk penyimpanan data yang akan ditampilkan di aplikasi. Untuk pembuatan tampilan web, penulis menggunakan framework CSS Bootstrap yang digunakan untuk membangun tampilan web.

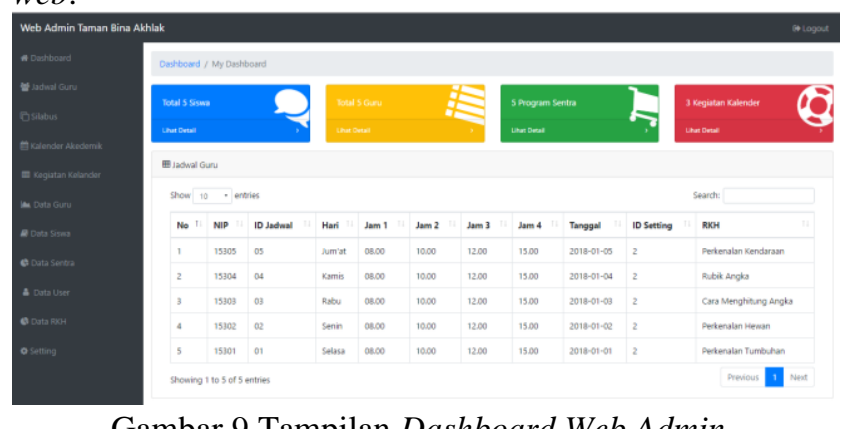

Gambar 9 Tampilan Dashboard Web Admin Sumber: penulis

Untuk mengubah tampilan web admin, penulis menggunakan text editor sublime text untuk mengedit atau mengubah tampilan web admin dari template yang telah diunduh. Sublime text yang digunakan penulis dalam pengeditan coding web admin aplikasi.

Setelah aplikasi selesai dirancang, penulis mem-build aplikasi melalui Android Studio. Setelah aplikasi jadi maka penulis melakukan testing untuk mengukur sejauh mana efektifitas aplikasi dapat digunakan baik dari segi usability maupun visibility. Aplikasi diuji coba pada berbagai jenis smartphone dengan spesifikasi minimun yang sudah ditetapkan. Hasilnya ialah bahwa aplikasi siap untuk digunakan dan sesuai dengan tujuan perancangan.

\section{PENUTUP}

\section{Kesimpulan}

Perancangan aplikasi yang akan dibuat adalah aplikasi yang memberikan informasi admnistrasi sekolah berbasis android. Aplikasi ini memberikan informasi program tahunan dan semester, isian silabus, data guru dan siswa, kalender akademik serta agenda guru setiap harinya. Aplikasi ini memudahkan guru untuk mendapatkan informasi dan mengakses informasi yang berhubungan dengan administrasi sekolah.

Tahapan pembuatan meliputi pra produksi yang mencakup perumusan ide dan curah pendapat serta pengumpulan data terkait, tahap produksi yang mencakup pembuatan aplikasi beserta kelengkapan fitur yang diperlukan, dan tahap pascaproduksi yang meliputi testing dan penyebaran penggunaan aplikasi.

\section{Saran}

Dari pembuatan aplikasi yang dilakukan, maka penulis mengajukan beberapa saran sebagai berikut:

1. dapat ditambahkan fitur administrasi lainnya seperti nilai atau bahkan status pembayaran siswa. 
2. data yang dibuat dapat diintegrasikan dengan cloud penyimpanan data sehingga data tetap terpelihara jika terjadi kerusakan memori penyimpanan data.

\section{DAFTAR PUSTAKA}

Asnawir. 2005. Administrasi Pendidikan. Padang: IAIN IB Press.

Davis, G. B. 2002. Sistem Informasi Manajemen. Jakarta: PT. Pustaka Binaman Pressindo.

Nawawi, H. 1997. Administrasi Pendidikan. Jakarta: Gunung Agung,

Honkis. 2017. Aplikasi Sistem Informasi Manajemen Sekolah Dasar Pilar Bangsa untuk Meningkatkan Layanan Pendidikan. Jurnal Administrasi Pendidikan, Vol. XXIV, No.2.

Musyafa, A. 2017. Perancangan Administrasi Sekolah Berbasis Dekstop. Jurnal Informatika, Vol. 2, No. 2. 